\title{
COMPARISON OF EU AND UKRAINE REGULATORY FRAMEWORK FOR BIOGAS PRODUCTION
}

\author{
Ye. Shapovalov, V. Shapovalov \\ National center of "Junior academy of science" \\ O. Salavor, I. Yakymeko \\ National University of Food Technology
}

\begin{tabular}{l}
$\quad$ Key words: \\
Eurointegration \\
Biogas production \\
Fertilizer \\
Harmonization \\
Waste utilization \\
\hline
\end{tabular}

Article history:

Received 10.09.2018

Received in revised form

26.09.2018

Accepted 11.10.2018

Corresponding author:

Ye. Shapovalov

E-mail:

npnuht@ukr.net

\begin{abstract}
The relevance of the analysis of the legislation of Ukraine and the EU is substantiated. It is described that the providing of methane fermentation with biogas production can reduce the emissions of carbon (IV) oxide up to $86 \%$. The purpose of the work was to analyze the regulatory framework for biogas production in Ukraine and the EU and to propose the aspects of harmonization. The object of the study is the legislation of Ukraine and the EU. The subject of the study is a way of harmonizing Ukrainian legislation to EU's legislation on biogas production. The analysis of the legislation concerning biogas production, waste, features of connection of biogas objects to the gas network, process control characteristics, fertilization and transportation was provided. The state of biogas technologies development in Ukraine and the EU is observed.
\end{abstract}

The strategies of development "Europe 2020" and "Ukraine 2020 " for biogas production are analyzed. It is substantiated that Ukrainian legislation is sufficiently harmonized with the EU legislation on biogas production and, in some aspects, is even more developed, in particular, obtaining biogas from landfills and disposing of excessive amounts of biofertilizer. However, some aspects of biogas production in Ukrainian legislation are not regulated enough and need to be harmonized with the EU legislation. There is better regulation of methane fermentation process control covered by the EU legislation. The aspects of stimulating waste utilization through methanogenesis are more specific in European legislation and include mitigation requirements for biogas installations and a revision of the regulatory framework for enhancing incentives. Strategic plans for the implementation of alternative sources in Ukraine are much less ambitious than in the EU.

DOI: $10.24263 / 2225-2924-2018-24-5-9$ 


\title{
ПОРІВНЯННЯ НОРМАТИВНОЇ БАЗИ ЄС \\ ТА УКРАЇНИ ЩОДО ВИРОБНИЦТВА БІОГАЗУ \\ 3 ОРГАНІЧНИХ ВІДХОДІВ
}

\author{
С.Б. Шаповалов, В.Б. Шаповалов
}

Наиіональний центр «Мала академія наук Украӥни»

О.М. Салавор, І.Л. Якименко

Національний університет харчових технологій

У статті обгрунтовано актуальність аналізу нормативної бази України та ЄС. Описано, що впровадження біогазових установок дасть змогу знизити викиди карбон (IV) оксиду на значення до 86\%. Проаналізовано нормативну базу щодо виробниџтва біогазу в Украйні та ЄС і визначено аспекти гармонізації. Об'єктом дослідження є нормативні бази України та СС. Предметом - иляхи гармонізаџії законодавства України до законодавства ЄС щчодо виробництва біогазу. Проведено аналіз законодавства, що стосується виробництва біогазу, щчодо відходів, особливостей підключення біогазових об'єктів до газомережі, особливостей контролю процесу, утворення добрив та їх транспортування, а також проаналізовано стан розвитку біогазових технологій в Україні та ЄС.

Проаналізовано стратегії розвитку «Європа 2020» та «Украӥна 2020» щодо виробництва біогазу. Обтрунтовано, щчо украӥнське законодавство $є$ досить гармонізованим із законодавством СС щодо виробництва біогазу та, в деяких аспектах, є навіть більш розвиненим, зокрема щодо отримання біогазу з полігонів ТПВ та утилізаиії надмірної кількості біодобрив. Однак окремі аспекти виробництва біогазу в украӥнському законодавстві врегульовані недостатньо та потребують гармонізаџї із законодавством СС. Дещо краще регулювання контролю прочесу метанової ферментачії висвітлено в законодавстві СС. Аспекти стимулювання утилізації відходів иляхом метаногенезу є більш конкретними у європейському законодавстві та передбачають пом'якшені вимоги щодо викидів біогазових установок і перегляд нормативної бази для покращення стимулювання. Стратегічні плани щьодо впровадження альтернативних джерел в Украйні є значно мени амбітними, ніж у СС, $і$ законодавство СС щодо менеджменту відходів стимулює впровадження біогазових технологій.

Ключові слова: євроінтеграчія, виробництво біогазу, дегістат, гармонізаиія, утилізаиія відходів.

Постановка проблеми. Утилізація відходів шляхом метанової ферментації є важливою складовою сталого розвитку. Це дає змогу забезпечити зниження викидів карбон (IV) оксиду, зокрема, у тваринництві. Так, відповідно до Директиви 2009/28/СС [18], метанова ферментація відходів може забезпечити зниження викидів парникових газів до 86\%. Ріст парникових газів протягом XX та XXI століть $є$ логарифмічним (рис. 1), що призводить до негативних наслідків - глобального потепління. 
Atmospheric $\mathrm{CO}_{2}(\mathrm{PPM})$

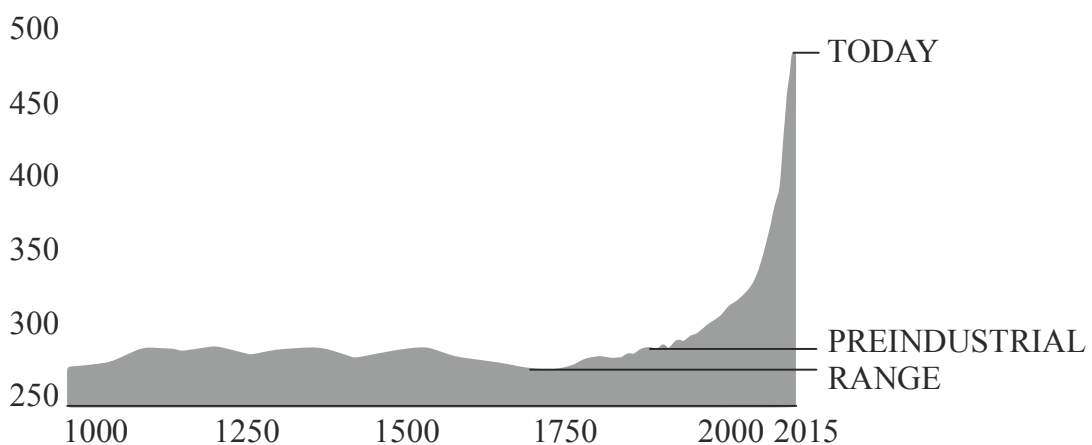

Рис. 1. Динаміка вмісту карбон (IV) оксиду

Особливості регулювання функціонування біогазових установок значною мірою впливають на поширення технології, тому порівняння нормативної бази в Україні та ЄС з цього напряму є актуальним.

Метою статті $є$ порівняння нормативної бази щодо впровадження біогазових технологій в Україні та ЄС.

Викладення основих результатів дослідження. Загальний стан нормативної бази щзодо виробництва біогазу. Стратегічні документи «Свропа 2020» [20] та «Україна 2020» [17] певною мірою передбачають впровадження біогазових технологій. Обидві стратегії передбачають впровадження альтернативних джерел енергіі, однак аспект щодо зниження викидів парникових газів зазначений лише у європейській стратегії. Порівняння стратегічних документів «Свропа 2020» та «Україна 2020» щодо метаногенезу відходів представлено у табл. 1 .

Таблиия 1. Порівняння стратегічних документів «Європа 2020» та «Україна 2020» щодо метаногенезу відходів [17, 20]

\begin{tabular}{|c|c|c|}
\hline Основні цілі & «Европа 2020» [20] & «Україна 2020» [17] \\
\hline Викиди парникових газів & $\begin{array}{c}\text { Зниження на 20\% } \\
\text { (порівняно 3 1990 р.) }\end{array}$ & Не регламентується \\
\hline $\begin{array}{c}\text { Отримання енергії з } \\
\text { відновлюваних джерел }\end{array}$ & $\begin{array}{c}\text { Забезпечення 20\% виробленої } \\
\text { енергії з відновлювальних } \\
\text { джерел }\end{array}$ & $\begin{array}{c}\text { Впровадження } \\
\text { альтернативних джерел } \\
\text { енергії }\end{array}$ \\
\hline
\end{tabular}

Загалом, у зв'язку із складністю процесу, регулювання відносин щодо виробництва біогазу здійснюється відповідно до законів і правових актів щодо атмосферного повітря, відходів, альтернативної енергетики, газотранспортної мережі та, власне, виробництва біогазу. Доцільно зазначити, що українське законодавство має більше статей, які регулюють виробництва та використання біогазу. Однак кількість спеціалізованих нормативно-правових актів, що реально впливають на врегулювання відносин при виробництві біогазу в Україні, є значно меншою порівняно із законодавством СС.

Законодавство ЄС передбачає стимулювання виробництва біогазу. Так, у ЄC впровадження біогазових технологій $є$ одним із критеріїв успішності 
проекту [33], для виробництва біогазу встановлюються м'якші вимоги щодо викидів парникових газів [24]. Крім того, законодавство СС стимулює виконання національних планів щодо впровадження відновлюваних джерел енергії (ВДЕ), передбачає співпрацю з іншими країнами [18] та інтенсифікацію розвитку біогазових проектів шляхом перегляду нормативної бази [19].

Українське законодавство також передбачає стимулювання виробництва біогазу, визначаючи, що він є одним 3 найбільш перспективних напрямків ВДЕ [15] та одним з шляхів зниження енергозалежності [16]. Окрім того, на сьогодні в Україні чинним є скасування реєстрів виробників біогазу [14].

Директивою 2009/28/EC [18] і Технічним регламентом 2016/426 [32] 3 боку СС, Законом України «Про ринок природного газу» [7] і постановою Національної комісії, що здійснює державне регулювання у сферах енергетики та комунальних послуг (Нацкомісія) «Про затвердження Кодексу газотранспортної системи» [12], затверджено можливість біогазу бути підключеним до газо- та енергомереж. Проте в Україні законодавством передбачається, що підприємства, які виробляють біогаз, самостійно забезпечують організацію прийому-передачі біогазу та облаштування місць відбору [11]. В той же час Директивою 2009/28/ЕС [18] регламентується пріоритетність використання енергії, отриманої з біогазу, на теренах ЄС.

На сьогодні Україна має досить високий зелений тариф для біогазу, що становить близько 0,14 С/кВТ год. Витяг із Закону України «Про електроенергетику» щодо «зеленого» тарифу представлений у табл. 2.

Таблиия 2. Витяг із Закону України «Про електроенергетику» щодо «зеленого» тарифу [2]

\begin{tabular}{|c|c|c|c|c|c|c|c|c|}
\hline \multirow[b]{2}{*}{\begin{tabular}{|} 
Категорії об’єктів \\
електроенергетики, \\
для яких \\
застосовується \\
«зелений» тариф
\end{tabular}} & \multicolumn{8}{|c|}{$\begin{array}{c}\text { Коефіцієнт «зеленого тарифу для об’єктів або його черг/пускових } \\
\text { комплексів, введених в експлуатацію» } \\
\end{array}$} \\
\hline & 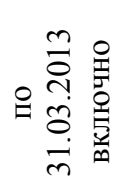 & 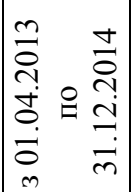 & 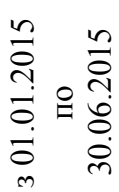 & 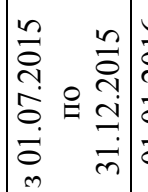 & 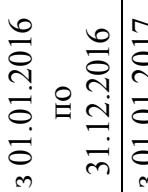 & 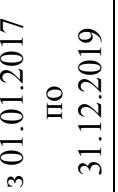 & 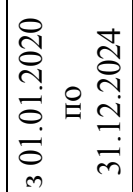 & 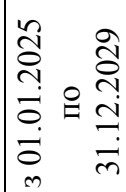 \\
\hline \begin{tabular}{|l|} 
для електроенергії \\
виробленої з біогазу
\end{tabular} & - & 2,30 & 2,07 & & 2,30 & & 2,07 & 4 \\
\hline
\end{tabular}

Положення щзодо утилізації відходів. Законодавство ЄС про відходи також позитивно впливає на розвиток біогазових технологій. Так, основні принципі СС щодо відходів такі: «забруднювач платить», «відповідальність виробника» та «принцип утилізації відходів на місці їх утворення» [25]. Окрім того, Директива 2008/98/ЄС регламентує порядок поводження з відходами: першочергове, запобігання утворенню відходів; а в разі, якщо це неможливо, необхідно утилізувати відходи з утворенням енергії; і лише в разі, якщо це неможливо, утилізувати (спалювати) відходи без отримання енергії; і в останню чергу - розміщувати відходи на сміттєзвалищах [25]. Враховуючи, що метаногенез відходів передбачає їх утилізацію з утворенням енергії, така технологія відповідає вимогам законодавства ЄС. 
Відповідно до статей 12-14 Технічного регламенту СС №1069/2009 [31] та Закону України «Про побічні продукти тваринного походження, не призначені для споживання людиною» [6] виробництво біогазу дозволяється з відходів тваринного походження другої й третьої категорії, якщо це не заборонено іншими законодавчими актами. Технічний регламент СС №185/2007 [21] вказує на метаногенез як один з перспективних напрямків утилізації тваринних відходів, а Директива 1999/31/СС [28] визнає, що метаногенез є одним із перспективних напрямків зниження забруднення навколишнього середовища при поводженні з відходами.

Додаткові нормативні документи, що врегульовують відносини у сфері поводження з відходами у ЄС та Україні, представлено у табл. 3.

Таблиия 3. Порівняння нормативних документів у СС та Україні щодо поводження з відходами

\begin{tabular}{|c|c|c|}
\hline Документ в ЄС & Предмет нормування & Аналог в Україні \\
\hline \begin{tabular}{|c|} 
Договір про функціонування \\
СС [23] \\
\end{tabular} & $\begin{array}{c}\text { Загальні аспекти щодо } \\
\text { споживання та виробництва }\end{array}$ & $\begin{array}{l}\text { Конституція України } \\
\text { (статті } 50 \text { та 66) [9] }\end{array}$ \\
\hline $\begin{array}{c}\text { Стратегія щодо відходів у } \\
\text { Європейській спільноті СОМ } \\
(96) 399 \text { [22] }\end{array}$ & $\begin{array}{c}\text { Утворення та транспортування } \\
\text { відходів }\end{array}$ & - \\
\hline $\begin{array}{c}\text { Директива 2008/98/ЄС } \\
\text { про відходи [25] }\end{array}$ & $\begin{array}{c}\text { Регламентує умови щодо } \\
\text { поводження з відходами, порядок } \\
\text { поводження з відходами }\end{array}$ & $\begin{array}{c}\text { Закон України «Про } \\
\text { відходи» [1], Класифіка- } \\
\text { тор відходів 005-96 [8] }\end{array}$ \\
\hline $\begin{array}{c}\text { Директива 2008/98/СС } \\
\text { про відходи [25] }\end{array}$ & $\begin{array}{c}\text { Визначає особливості } \\
\text { поводження з небезпечними } \\
\text { відходами } \\
\end{array}$ & $\begin{array}{c}\text { Закон України «Про } \\
\text { відходи» [4], ДК 005-96 } \\
{[5]} \\
\end{array}$ \\
\hline $\begin{array}{c}\text { Директива 2008/98/СС } \\
\text { про відходи [25] }\end{array}$ & $\begin{array}{c}\text { Особливості транспортування } \\
\text { відходів }\end{array}$ & $\begin{array}{c}\text { Закон України «Про } \\
\text { відходи» [4] }\end{array}$ \\
\hline $\begin{array}{l}\text { Директива 1999/31 щодо } \\
\text { відходів на полігонах [28] }\end{array}$ & $\begin{array}{c}\text { Особливості захоронення } \\
\text { відходів та визначає види } \\
\text { полігонів }\end{array}$ & $\begin{array}{c}\text { Закон України «Про } \\
\text { відходи» [4] }\end{array}$ \\
\hline
\end{tabular}

Відповідно до постанови Нацкомісії «Про затвердження Ліцензійних умов провадження господарської діяльності з захоронення побутових відходів» [13] полігони твердих побутових відходів (ТПВ) повинні бути забезпеченими системами збору біогазу. На нашу думку, виконання цього зобов'язання у повному обсязі є досить складним. Однак відомо, що на сьогодні полігони ТПВ в Україні досить стрімко оснащуються системами збору біогазу.

Реалізаиія утворених добрив. Законодавство ЄС та України передбачають можливість розміщення на ринку утвореного дегістату [6; 31]. В українському законодавстві добриво, отримане з відходів шляхом метанової ферментації, входить до переліку добрив і покращувачів грунту як окремий пункт «дегістат біогазу, який містить похідні продукти, що компостуються 3 матеріалами рослинного і тваринного походження, зазначеними в цьому додатку» [10]. Окрім того, існує британський стандарт щодо біогазового дегістату PAS 110:2014 [29], однак українського стандарту щодо добрив немає. Відповідно до Закону України «Про відходи» [4] забороняється будувати біогазові установки без систем утилізації рідкої фази. 
Відповідно до ДСТУ 4516:2006 «Енергоощадність. Поновлювані джерела енергії. Установки біогазові. Загальні технічні вимоги» добриво, отримане внаслідок роботи БГУ, має бути виконано у формі гранул, висушених до вологості не більше $12 \%$ за температури $20^{\circ} \mathrm{C}$.

Отже, реалізація дегістату, на нашу думку, стимулюється українським законодавством краще та є більш прогресивним, хоча на практиці такий ефект непомітний.

Контроль проиесу. Законодавство ЄС зобов'язує враховувати розробки стандартів Європейського комітету стандартизації (CEN) при впровадженні біогазових технологій [26]. Окрім того, на біогазових установках повинна бути запроваджена система НАССР [31].

В Україні біогазові установки повинні відповідати ДСТУ 4516:2006 «Енергоощадність. Поновлювані джерела енергії. Установки біогазові. Загальні технічні вимоги», ДСТУ 7014:2009 «Установки біогазові присадибні. Загальні технічні вимоги» або за технічними умовами.

Транспортування. Транспортування продуктів метаногенезу до країн, що не $\epsilon$ членами OECD, заборонене [31]. Метаногенний ефлюент може бути транспортований лише за умови, якщо адміністрація держави-члена відправника поінформувала адміністрацію держави-члена отримувача та між ними була підписана угода [30].

Законодавство України частково відповідає законодавству ЄС у цій сфері. Проте доцільно зазначити, що в деяких аспектах українське законодавство $\epsilon$ більш прогресивним, зокрема щодо отримання біогазу з полігонів ТПВ й утилізації надлишкового дегістату. Порівняння законодавчої бази України та ЄС щодо відходів представлено у табл. 4.

Таблиия 4. Порівняння законодавчої бази України та СС щодо виробництва біогазу

\begin{tabular}{|c|c|c|}
\hline Напрям & \begin{tabular}{|l} 
Відповідність законодавства \\
України нормативній базі ЄС
\end{tabular} & Пропозиція/коментар \\
\hline Загальні положення & Досить повна відповідність & $\begin{array}{c}\text { Гармонізувати положення } \\
\text { законодавства ЄС щодо } \\
\text { стимулювання виробництва } \\
\text { біогазу }\end{array}$ \\
\hline $\begin{array}{c}\text { Положення щодо } \\
\text { поводження з біогазом }\end{array}$ & Повна відповідність & - \\
\hline $\begin{array}{c}\text { Положення щодо } \\
\text { поводження з відходами }\end{array}$ & Досить повна відповідність & $\begin{array}{c}\text { Гармонізувати ієрархію } \\
\text { поводження з відходами та } \\
\text { класифікацію відходів } \\
\end{array}$ \\
\hline Положення щодо біодобрив & $\begin{array}{c}\text { Повна відповідність, } \\
\text { українське законодавство є } \\
\text { більш цілісним і глибоким }\end{array}$ & $\begin{array}{c}\text { В українському законодавстві } \\
\text { висвітлено аспект щодо } \\
\text { необхідності утилізації } \\
\text { надлишкового біодобрива }\end{array}$ \\
\hline $\begin{array}{c}\text { Положення щодо контролю } \\
\text { процесу }\end{array}$ & $\begin{array}{l}\text { Висока ступінь } \\
\text { невідповідності }\end{array}$ & $\begin{array}{c}\text { Гармонізувати аспекти щодо } \\
\text { контролю процесу }\end{array}$ \\
\hline Транспортування & $\begin{array}{c}\text { Відсутність відповідності, } \\
\text { українське законодавство не } \\
\text { враховує аспекти } \\
\text { транспортування відходів }\end{array}$ & $\begin{array}{c}\text { Гармонізувати особливості } \\
\text { транспортування відходів }\end{array}$ \\
\hline
\end{tabular}


Стан галузі. Станом на 2018 р. в Україні діє близько 40 об'єктів, які є виробниками біогазу. Цього замало, порівнюючи з показниками європейських країн. Так, у Німеччині, відповідно до статистики Свропейської біогазової асоціації, функціонує майже 11 тис. біогазових установок. Отже, ймовірно, законодавство $€ С$ врегульовує відносити щодо виробництва біогазу дещо ефективніше. Загальна статистика щодо впровадження біогазових технологій у ЄС представлена на рис. 2.

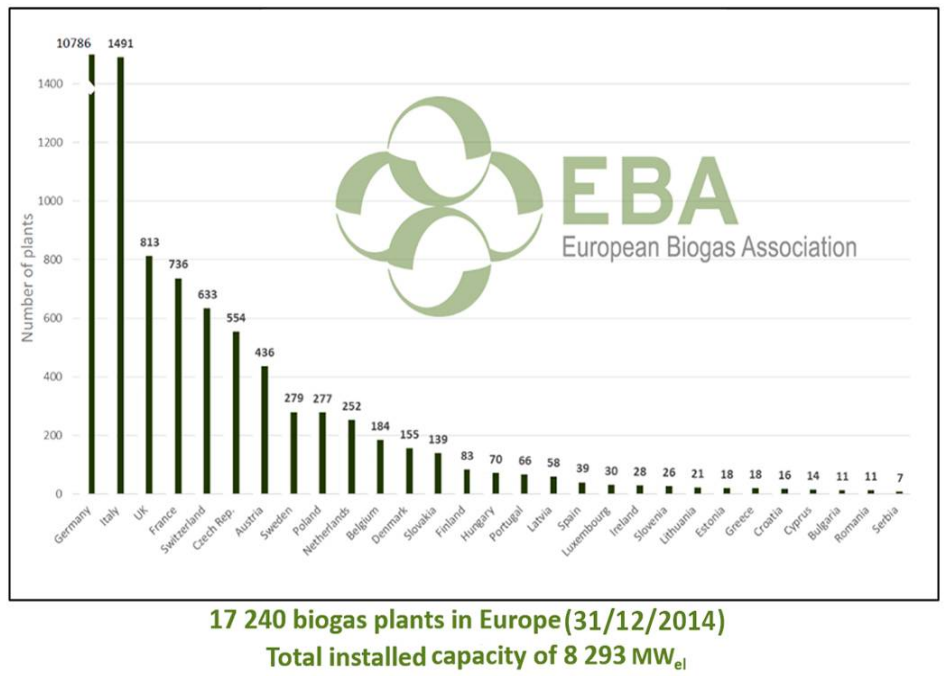

Рис. 2. Кількість біогазових установок у краӥнах СС у 2014 р. [27]

\section{Висновки}

1. Вперше проведено порівняльний аналіз законодавства України та СС щодо отримання біогазу з органічних відходів.

2. 3'ясовано, що ряд нормативних документів ураховують досвід СС і гармонізовані з європейським законодавством.

3. Дещо більш розвинутим є українське законодавство щодо утилізації надлишкового дегістату та щодо отримання біогазу з полігонів ТПВ.

4. Запропоновано гармонізувати законодавство України з законодавством ЄС щодо поводження з відходами, траспортування дегістату та особливостей контролю метаногенезу відходів.

\section{Література}

1. Державний стандарт України. ДСТУ 3803-98 «Біотехнологія. Терміни і визначення», видання офіційне. Київ: ДЕРЖАСТАНДАРТ УКРАЇНИ, 1999 р.

2. Державний стандарт України. ДСТУ 4516:2006 «Енергоощадність. Поновлювачі джерела енергії установки біогазові. Загальні технічні вимоги», видання офіційне. Київ: Держстандарт України, 1999 р.

3. Державний стандарт України. ДСТУ 7014:2009 «Установки біогазові присадибні. Загальні технічні вимоги», видання офіційне. Київ: Держстандарт України, 2006 р.

4. Закон України «Про відходи». Верховна Рада України. 1998. URL: http://zakon.rada.gov.ua/laws/show/187/98-\%D0\%B2\%D1\%80.

5. Закон України «Про електроенергетику». Верховна Рада України. 1998. URL: http://zakon.rada.gov.ua/laws/show/575/97-\%D0\%B2\%D1\%80. 
6. Закон України «Про побічні продукти тваринного походження, не призначені для споживання людиною». Верховна Рада України. 2015. URL: http://zakon.rada.gov.ua/laws/show/287-19.

7. Закон України «Про ринок природного газу». Верховна Рада України. 2016. URL: http://zakon.rada.gov.ua/laws/show/329-19.

8. Класифікатор відходів ДК 005-96. ДЕРЖАВНИЙ КОМІТЕТ УКРАЇНИ ПО СТАНДАРТИЗАЦІї, МЕТРОЛОГІЇ ТА СЕРТИФІКАЦІЇ. 1996. URL: http://plast.vn.ua/DK005-96.html.

9. Конституція України. Відомості Верховної Ради України. 1992. URL: http://zakon3.rada.gov.ua/laws/show/254\%D0\%BA/96-\%D0\%B2\%D1\%80.

10. Постанова Кабінету Міністрів «Про затвердження переліків вхідних продуктів, які дозволяється зберігати у виробничому підрозділі» від 9 грудня 2015 р. № 1023. Кабінет Міністрів України. 2015. URL: http://zakon.rada.gov.ua/laws/show/1023-2015-\%D0\%BF.

11. Постанова Національної комісії, що здійснює державне регулювання у сферах енергетики та комунальних послуг про «Про затвердження Кодексу газорозподільних систем» від 30.09.2015 № 2494Національна комісія, що здійснює державне регулювання у сферах енергетики та комунальних послуг. 2015. URL: http://zakon.rada.gov.ua/laws/show/z1379-15.

12. Постанова Національної комісії, що здійснює державне регулювання у сферах енергетики та комунальних послуг «Про затвердження Кодексу газотранспортної системи» від 30.09.2015 № 2493. Національна комісія, що здійснює державне регулювання у сферах енергетики та комунальних послуг. 2015. URL: http://zakon.rada.gov.ua/laws/show/z1378-15.

13. Постанова Національної комісії, що здійснює державне регулювання у сферах енергетики та комунальних послуг «Про затвердження Ліцензійних умов провадження господарської діяльності з захоронення побутових відходів» від 04.04.2017 № 467. Національна комісія, що здійснює державне регулювання у сферах енергетики та комунальних послуг. 2017. URL: http://zakon.rada.gov.ua/laws/show/v0467874-17.

14. Розпорядження Кабінету Міністрів «Про затвердження плану заходів щодо дерегуляції господарської діяльності та визнання такими, що втратили чинність, деяких розпоряджень Кабінету Міністрів України» від 23 серпня 2016 р. № 615-рКабінет Міністрів України. 2016. URL: http://zakon.rada.gov.ua/laws/show/615-2016-\%D1\%80.

15. Розпорядження Кабінету Міністрів України «Про схвалення Концепції Державної цільової науково-технічної програми розвитку виробництва та використання біологічних видів палива» від від 12 лютого 2009 р. N 276-р. Кабінет Міністрів України. 2009. URL: http://zakon.rada.gov.ua/laws/show/276-2009-\%D1\%80.

16. Угода між Міністерством енергетики та вугільної промисловості України та Міністерством закордонних справ Королівства Данія про продовження співробітництва у сфері розвитку та діяльності Українсько-данського енергетичного центру. Міністерство енергетики та вугільної промисловості України (Міненерговугілля України), Королівство Данія. 2018. URL: http://zakon.rada.gov.ua/laws/show/208_001-18.

17. Указ Президента України «СТРАТЕГІЯ сталого розвитку “Україна-2020”». 2015. URL: http://zakon3.rada.gov.ua/laws/show/5/2015.

18. Directive 2009/28/EC of the European Parliament and of the Council of 23 April 2009 on the promotion of the use of energy from renewable sources and amending and subsequently repealing Directives 2001/77/EC and 2003/30/EC (Text with EEA relevance). European Commision. 2009. URL: https://eur-lex.europa.eu/legal-content/EN/TXT/?uri=CELEX:32009L0028.

19. Brussels, $\operatorname{COM}(2005) 628$. Encouraging the use of biomass as an alternative source of energy. URL: https://eur-lex.europa.eu/legal-content/EN/TXT/?uri=legissum:127014.

20. Brussels, COM(2010) 2020. Europe 2020. URL: http://ec.europa.eu/eu2020/pdf/COMPLET\%20EN\%20BARROSO \%20\%20\%20007\%20-\%20Europe $\% 202020 \% 20$ - \%20EN $\% 20$ version.pdf. 


\section{BIOTECHNOLOGIES}

21. COMMISSION REGULATION (EC) No 185/2007 of 20 February 2007 amending Regulations (EC) No 809/2003 and (EC) No 810/2003 as regards extension of the validity of the transitional measures for composting and biogas plants under Regulation (EC) No 1774/2002 of. European Commision. 2007. URL: https://eur-lex.europa.eu/LexUriServ/LexUriServ.do?uri=OJ:L:2007:063:0004:0005:EN:PDF.

22. COMMUNICATION FROM THE COMMISSION on the review of the Community Strategy $\sim$ for Waste Management. Brussels, 30.07.1996 COM(96) 399 final. 1996. URL: http://aei.pitt.edu/4116/1/4116.pdf.

23. CONSOLIDATED VERSION OF THE TREATY ON THE FUNCTIONING OF THE EUROPEAN UNION. Official Journal of the European Union. 2012. URL: https://eur-lex.europa.eu/legal-content/EN/TXT/?uri=celex\%3A12012E\%2FTXT.

24. Directive (EU) 2015/2193 of the European Parliament and of the Council of 25 November 2015 on the limitation of emissions of certain pollutants into the air from medium combustion plants (Text with EEA relevance). European Commision. 2015. URL: https://eur-lex.europa.eu/legalcontent/en/ALL/?uri=CELEX:32015L2193.

25. Directive 2008/98/EC of the European Parliament and of the Council of 19 November 2008 on waste and repealing certain Directives (Text with EEA relevance) [Електронний pecypc]. — European Commision. 2008. — Режим доступу : https://eur-lex.europa.eu/legalcontent/EN/TXT/?uri=CELEX\%3A32008L0098.

26. Directive 2012/18/EU of the European Parliament and of the Council of 4 July 2012 on the control of major-accident hazards involving dangerous substances, amending and subsequently repealing Council Directive 96/82/EC Text with EEA relevance. European Commision. 2012. URL: https://eur-lex.europa.eu/legal-content/en/ALL/?uri=CELEX:320$12 \mathrm{~L} 0018$.

27. EBA Biomethane \& Biogas Report 2015. European Biogas Association. 2015. URL: http://european-biogas.eu/2015/12/16/biogasreport2015/.

28. Council Directive 1999/31/EC of 26 April 1999 on the landfill of waste. European Commision. 1999. URL: https://eur-lex.europa.eu/legal-content/EN/TXT/?uri=celex\%3A31999L0031.

29. PAS 110:2014 Specification for whole digestate, separated liquor and separated fibre derived from the anaerobic digestion of source-segregated biodegradable materials. BSI Standards Limited. 2014. URL: https://static1.squarespace.com/static/56dla94elbbee09a4bc6c578/t/56d4ba502b8ddea29eb2872f/1456781906892/PAS110_2014_final.pdf.

30. Regulation (EC) No 1013/2006 of the European Parliament and of the Council of $14 \mathrm{Ju}-$ ne 2006 on shipments of waste. [European Commision. 2006. URL: https://eur-lex.europa.eu/legal-content/en/TXT/?uri=CELEX:32006R1013.

31. Regulation (EC) No 1069/2009 of the European Parliament and of the Council of 21 October 2009 laying down health rules as regards animal by-products and derived products not intended for human consumption and repealing Regulation (EC) No 1774/2002 (Animal) European Commision. 2009. URL: https://eur-lex.europa.eu/legal-content/EN/ALL/?uri=CELEX\%3A32009R1069.

32. Regulation (EU) 2016/426 of the European Parliament and of the Council of 9 March 2016 on appliances burning gaseous fuels and repealing Directive 2009/142/EC (Text with EEA relevance). European Commision. 2016. URL: https://eur-lex.europa.eu/legal-content/EN/TXT/?uri=CELEX\%3A32016R0426.

33. Regulation (EU) No 347/2013 of the European Parliament and of the Council of 17 April 2013 on guidelines for trans-European energy infrastructure and repealing Decision No 1364/2006/EC and amending Regulations (EC) No 713/2009, (EC) No 714/2009 and (EC) N. European Commision. 2013. URL: https://eur-lex.europa.eu/legal-content/en/TXT/?uri=celex\%3A32013R0347. 